\title{
A mística litúrgica cristã A mistagogia hoje à luz da Constituição Sacrosanctum Concilium
}

Orientador: Luiz Fernando Ribeiro Santana

Doutorando: Vitor Gino Finelon

Área de Concentração: Teologia Sistemático-Pastoral

Linha de Pesquisa: Fé e Cultura

Projeto de Pesquisa: Questões atuais de Teologia Litúrgica

A teologia litúrgica tem se interessado por reunir os conceitos de mistério, mistagogia e mística. Nosso trabalho quer contribuir para avançar os debates atuais. Para isso, pesquisamos a noção de mistério segundo a Teologia desenvolvida nos artigos segundo, quinto e sexto da constituição sobre a sagrada liturgia do Concílio Vaticano II. Para a Teologia Conciliar, o mistério é a salvação do Pai, efetivada pelo Filho, comunicada pelo Espírito Santo, através da igreja em sua dupla missão: anúncio e celebração. Depois, apresentamos o trabalho de recuperação e atualização da experiência mistagógica no transcurso dos últimos anos. A mistagogia atual é abordada em chave catequética (catequese mistagógica e iniciação cristã), litúrgica (teologia litúrgica) e espiritual (mística litúrgica). Finalmente, nos dedicamos à compreensão do fenômeno da mística cristã em consonância com as noções teológico-pastorais do conceito de mistério e de mistagogia. A mística litúrgica cristã é aquela na qual os iniciados experimentam na sua vida a força comunicativo-terapêutica do mistério pascal de Cristo. A conclusão obtida é que o trinômio mistério-mistagogia-mística, por serem indissociáveis, precisam penetrar e se consolidar na Teologia e práxis eclesial.

Palavras-chave: Mística. Mistério. Mistagogia. Sacrosanctum Concilium. Teologia litúrgica. 